Research.

\title{
ANALYSIS OF THE FACTORS THAT AFFECT THE COMPANY'S ACCOUNTING CONSERVATISM
}

\author{
Wulan Wahyuni Rossa Putri ${ }^{1)^{\star}}$, Nilda Tartilla ${ }^{2)}$, M. Nofal Pamungkas ${ }^{3)}$ \\ Department of Accountancy, Institut Bisnis \& Informatika Kesatuan Bogor \\ 1)*wulwahyuni@gmail.com; ${ }^{2}$ nildatartilla@gmail.com; ${ }^{3}$ nofalwibisana13@gmail.com \\ * Corresponding author
}

Received: September 28, 2020; Accepted: November 14, 2020; Published: December 31, 2020

To cite this article: Putri, W.W.R, Tartilla,N \& Pamungkas,M.N. (2020). Analysis Of The Factors That Affect The Company's Accounting Conservatism. The Accounting Journal of BINANIAGA, 5 (2),101-112 doi: 10.33062/ajb.v5i2.391

\begin{abstract}
Accounting conservatism is a precautionary principle in financial reporting. In this principle, it slows down the recognition of revenue and accelerates the recognition of costs so as to result in lower profits and assets, as well as high costs and debt. The population of this research is manufacturing companies listed on the Indonesia Stock Exchange, with research samples in the Property Real Estate and Buliding Construction sector in the 2013-2017 period. The analysis method used in this research is multiple regression with the SPSS version 25 program and hypothesis testing is done using multiple linear regression method. The results of this research indicate that leverage has no effect on accounting conservatism with a significance value of 0.554 . Financial distress has no effect on accounting conservatism with a value of 0.852. Meanwhile, capital intensity has an effect on accounting conservatism with a significance value of 0.000. As well as Leverage, Financial Distress, and Capital Intensity simultaneously affect accounting conservatism.
\end{abstract}

Key words: Accounting Conservatism, Leverage, Financial Distress, Capital Intensity.

\section{INTRODUCTION}

Accounting conservatism based on Financial Accounting Standards (SAK) is still applied in the choice of accounting methods, whereas according to IFRS (International Financial Report Standard) the concept of accounting conservatism had been replaced by the concept of prudence, but its use is still maintained in certain areas (Hellman , 2007). The principle of conservatism is a principle that slows down the valuation of income and accelerates the valuation of costs, valuing assets that are lower and liabilities are valued higher, conservatism anticipates losses rather than profits. So that it will affect earnings information in the future

Conservatism is measured using the net asset measure (Beaver and Ryan, 2020) which is proxied by using the market to book ratio which reflects the book value of the company's equity to relative market value, the market value in this study uses the closing stock market value or price, it is the last share price on December 31. Below is a table of the development of accounting conservatism in manufacturing companies in the Property Real Estate and Building Construction sector in the period of 2013 - 2017:

Wulan Wahyuni Rossa Putri, Nilda Tartilla and M. Nofal Pamungkas. Analysis Of The Factors That Affect The Company's Accounting Conservatism 
The Accounting Journal of BINANIAGA Vol. 05, No. 02, December 2020

p-ISSN: 2527-4309, e-ISSN: 2580-1481

$5^{\text {th }}$ Accreditation Rating: January 14, 2019 - January 13, 2024

Table 1 Development of Accounting Conservatism

\begin{tabular}{lrrrrr}
\hline Year & 2013 & 2014 & 2015 & 2016 & 2017 \\
\hline Accounting Conservatism & $20,36 \%$ & $27,74 \%$ & $20,00 \%$ & $16,71 \%$ & $15,18 \%$ \\
\hline Source: processed data, 2020 & & & & &
\end{tabular}

When illustrated with the following chart:

Chart of Development of Accounting Conservatism

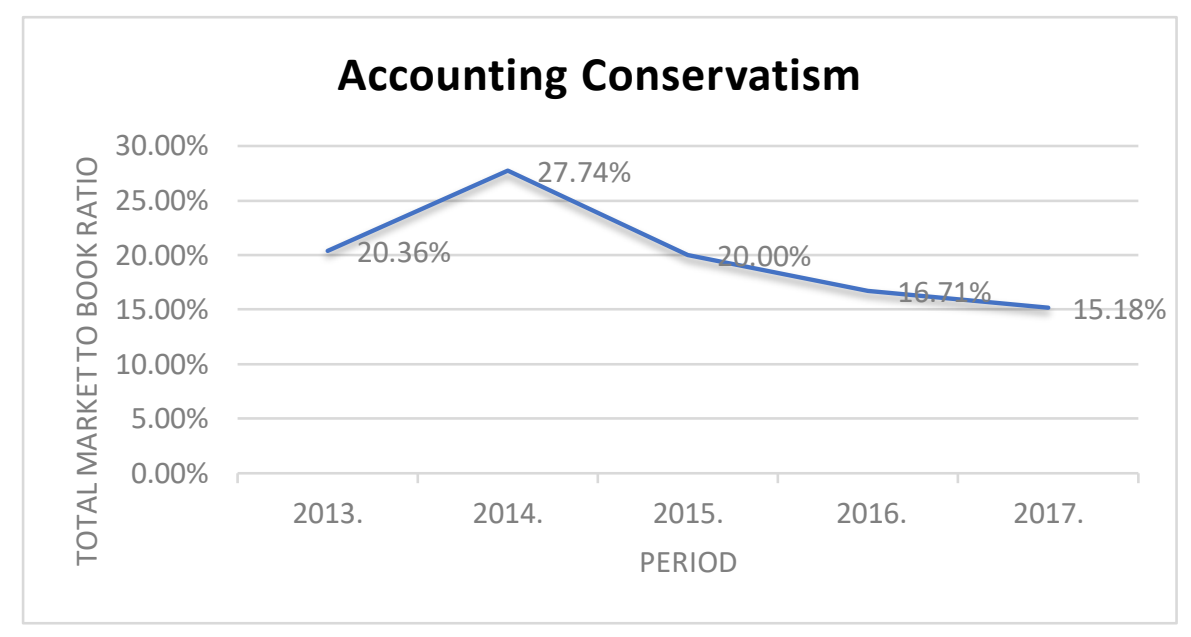

When seen in the chart above, there is an increase in accounting conservatism as measured by the market to book ratio in 2014, while from 2015 to 2017 there was a decrease in accounting conservatism. Many factors can cause the decline in accounting conservatism, one of which is accounting conservatism which is still seen as a controversial accounting principle. Accounting conservatism is seen as affecting the quality of financial reports because the principle of conservatism accelerates the valuation of costs and slows down the valuation of income so that it will affect the value of future earnings. But accounting conservatism also has the benefit of avoiding the opportunistic behaviour of managers (Alif Lailatul, 2016).

Based on the controversy over accounting conservatism, this research will examine other factors that influence accounting conservatism, including leverage, financial distress, and capital intensity. Leverage analysis describes the relationship between company debt and company capital, and assets which will analyse, how much the company is financed by debt. (Sofyan Safri, 2011: 306).

Financial distress is measured by using DER (Debt to Equity Ratio), to find out how much the symptoms or signs (signals) that occurred in the company before it went bankrupt to financial conditions, financial difficulties when the company was unable to pay its obligations and the level of this financial difficulty would affect accounting conservatism. Capital intensity is measured by the ratio between sales received and total assets received by the company (Sari, 2009).

Capital intensity leads to how the company is capital intensive, how large assets will be used by the company to generate sales of the company's products. With a capital intensive will carry out reporting conservatively or tend to reduce profits.

Wulan Wahyuni Rossa Putri, Nilda Tartilla and M. Nofal Pamungkas. Analysis Of The Factors That Affect The Company's Accounting Conservatism 
Research conducted by Alif Lailatul (2016) states that, leverage, financial distress and company size affect accounting conservatism. This is supported by research conducted by Desak Gede Utami (2013). Research conducted by Angga Alfian (2013) states that, capital intensity has a positive effect on accounting conservatism, which is supported by research conducted by Sari and Adhariani (2009). Based on this description, the researcher will take the research title, "Analysis of the Factors that Affect Company's Accounting Conservatism ", with the object of research being manufacturing companies in the Property Real Estate and Building Construction sector from 2013 to 2017.

\section{LIBRARY REVIEW}

Conservatism according to Watts (2003) defines that accounting conservatism arises from incentives related to contract, litigation, tax and political costs that are beneficial for companies to reduce agency costs and reduce excessive payments to parties such as managers, shareholders, courts, and government. In addition, conservatism also causes understatement of earnings in the current period which can lead to overstatement of earnings in subsequent periods, as a result of understatement of costs in that period.

Kim and Zhang, (2013: 43) define leverage as the ratio of long-term debt to total assets. Noor, Fadzillah and Matsuki (2010: 190) define leverage as total debt divided by total assets. According to Rajan and Zingales (1995) in Djebali and Belanes (2012: 181) financial leverage is the ratio of debt (both long-term and short-term debt) to total assets. According to Adhikari, Derashid and Zhang (2006: 584) leverage is the ratio of total debt divided by total assets.

Altman in Rodoni and Ali (2010: 172) defines financial distress as the inability to pay debt (insolvency), the condition of a person's assets or property and liabilities that were previously available to be insufficient to pay off debts.

According to Noor et al., (2010: 190) Capital intensity is defined as the ratio between fixed assets such as equipment, machinery and various properties to total assets. This ratio describes how much the company's assets are invested in fixed assets. Based on the literature review, the research framework is as follows:

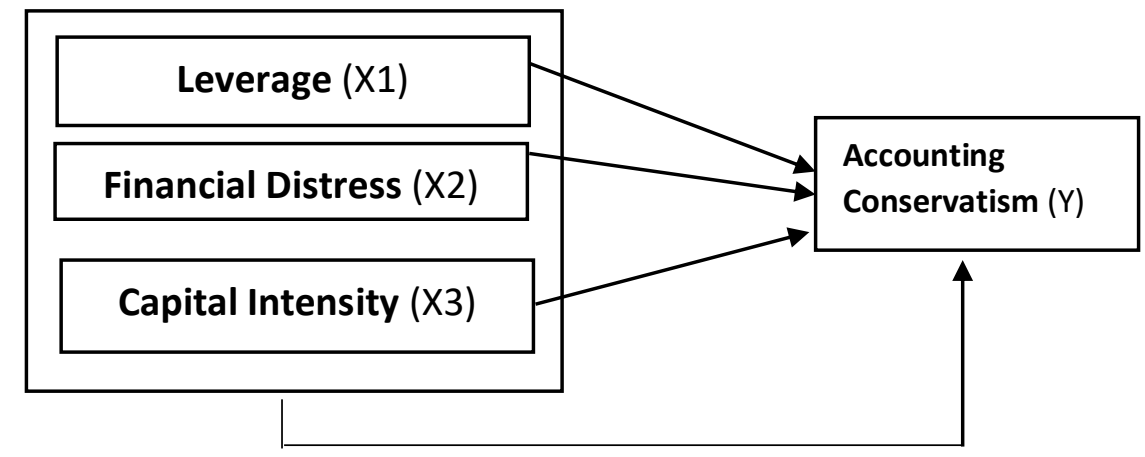

Based on the research framework, the research hypothesis that can be proposed is as follows:

$\mathrm{H} 1$ : Leverage ratio has a positive effect on accounting conservatism,

H2: Financial distress has a positive effect on accounting conservatism,

H3: Capital intensity has a positive effect on accounting conservatism,

$\mathrm{H} 4$ : leverage, financial distress, and capital intensity simultaneous influence on accounting conservatism.

Wulan Wahyuni Rossa Putri, Nilda Tartilla and M. Nofal Pamungkas. Analysis Of The Factors That Affect The Company's Accounting Conservatism 


\section{RESEARCH METHODOLOGY}

\section{Population and Sample}

The population of this study is manufacturing companies listed on the Indonesia Stock Exchange, with research samples from the Property Real Estate and Building Construction sector in the period of $2013-2017$.

\section{Research Variables}

This research consists of the following variables:

1. Independent Variable

In this study the variable $X$ consists of:

1) Leverage

Can be described by the formula:

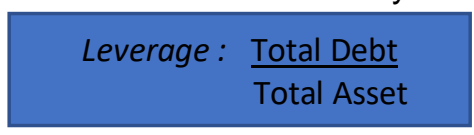

2) Financial Distress

The indicator or proxy for financial distress is the DER (Debt to Equity Ratio) ratio. The DER formula is:

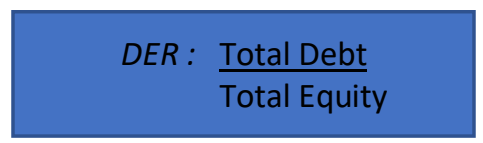

3) Capital Intensity

Capital intensity is measured by the ratio between the sales received and the total assets owned by the company according to Watts' book on positive accounting theory.

It can be described by the following formula:

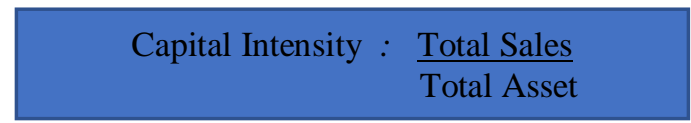

2. Dependent Variables

Accounting conservatism proxies using the market to book ratio. The formula for calculating the market to book ratio is:

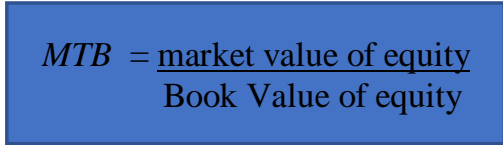

\section{Data Analysis Technique}

.The data analysis in this research began with the classical assumption test, compiling multiple linear regression equations, then carried out, and testing the hypothesis.

\section{Classical Assumption Test}

Classical Assumption Test used in this research, they are:

\section{Normality Test}

The normality test used in this study was the Kolmogorov-Smirnov test for the SPSS program. The significance of the Kolmogorov test is, if the significance is below 0.05 , it

Wulan Wahyuni Rossa Putri, Nilda Tartilla and M. Nofal Pamungkas. Analysis Of The Factors That Affect The Company's Accounting Conservatism 
means that there is a significant difference with the standard normal data, so it can be concluded that the data used is not normal.

\section{Multicollinearity Test}

To detect whether there is multicollinearity in the regression, it can be seen from: (1) tolerance value, (2) variance inflation factor (VIF) value. Regression models that are free of multicollinearity are those that have a tolerance value above 0.1 or a VIF below 10 (Ghozali, 2006: 105). If the tolerance variance is below 0.1 or VIF is above 10 , then multicollinearity occurs.

\section{Heteroscedasticity Test}

There is one way to detect the presence or absence of heteroscedasticity, is by looking at the plot graph between the predicted value of the dependent variable, namely ZPRED and the residual SRESID. Detection of the presence or absence of heteroscedasticity can be done by looking at the presence or absence of a certain pattern on the scatterplot graph between SRESID and ZPRED where the $Y$ axis is the predicted $Y$, and the $X$ axis is the studentized residual. If there is a certain pattern such as the existing dots forming a certain regular pattern, it indicates that heteroscedasticity has occurred, if there is no clear pattern, and the dots spread above and below the number 0 on the $Y$ axis, then there is no heteroscedasticity , 2006: 139).

\section{Autocorrelation Test}

The autocorrelation test aims to test, whether in a linear regression model there is a correlation between confounding error in period $t$ and confounding error in period $t-1$ (previous). If there is a correlation, it is called an autocorrelation problem (Ghozali, 2006: 110). To detect the presence or absence of autocorrelation, a Durbin-Watson (DW) test is performed with the following conditions:

1) If the DW value is between the upper bound (du) and (4-du), the autocorrelation coefficient $=0$, meaning no there is autocorrelation.

2) If the DW value is lower than the lower bound ( $\mathrm{dl}$ ), then the autocorrelation coefficient is $>0$, meaning there is positive autocorrelation.

3) If the DW value is greater than (4-dl) then the autocorrelation coefficient is $<0$, it means that there is negative autocorrelation.

4) If the DW value lies between du and dl or the DW lies between (4-du) and (4-dl) then the result cannot be concluded.

\section{Multiple Linear Regression Analysis}

Linear regression is used to obtain a mathematical relationship in the form of an equation between the dependent variable and the independent variable. The form of the linear regression equation, namely:

$$
Y=\alpha+\beta X_{1}+\beta X_{2}+\beta X_{3}+\varepsilon
$$

\section{Caption:}

$\mathrm{Y}=$ dependent variable

$\alpha=$ intersection or constant

$\beta=$ regression coefficient

$\mathrm{X} 1=$ variable leverage

$\mathrm{X} 2=$ variable financial distress

$\mathrm{X} 3=$ variable capital intensity

$\varepsilon=$ error rate

Wulan Wahyuni Rossa Putri, Nilda Tartilla and M. Nofal Pamungkas. Analysis Of The Factors That Affect The Company's Accounting Conservatism 


\section{Hypothesis Test}

\section{Coefficient of Determination (R2)}

The coefficient of determination $\left(R^{2}\right)$ essentially measures how far the model's ability to explain the variation in the independent variable. A small value of $R^{2}$ means that the ability of the independent variables to explain variations in the dependent variable is very limited, preferably a $R^{2}$ value that is close to one means that the independent variables provide almost all the information needed to predict the variation in the dependent variable (Ghozali, 2011: 97).

\section{Simultaneous Hypothesis Test (F Test)}

The $F$ test is carried out to test the level of influence of the independent variable on the dependent variable simultaneously (Ghozali, 2006). This test is carried out by a two-way test with the hypothesis:

$\mathrm{H} 0: \mathrm{X} 1=\mathrm{X} 2=\mathrm{X} 3=\mathrm{X} 4$, meaning that there is no significant effect of the independent variables on the dependent variable together.

Ha: X1. X2. X3 .X3. X4 means that there is a significant effect of the independent variable on the dependent variable together. The test criteria are defined as follows:

1. If Fcount $<$ Ftable, $\mathrm{Ho}$ is accepted and $\mathrm{Ha}$ is rejected.

2. If Fcount $>$ Ftable $\mathrm{Ho}$ is rejected and accepts $\mathrm{Ha}$.

\section{Hypothesis Test Partially (t Test)}

The $t$ test was conducted to partially test the significance level of the effect of the independent variable on the dependent variable. This test is carried out by a two-way test with the hypothesis:

$\mathrm{Ho}: \mathrm{Xi}=0$, meaning that there is no significant effect of the independent variable on the dependent variable.

Ho: Xi \# 0, meaning that there is a significant effect of the independent variable on the dependent variable. The test criteria are defined as follows:

1. If the value-tcount $>$-table or tcount $<t$ table, then $\mathrm{Ho}$ is accepted,

2. If the tcount $>$ ttable or -thitung $<-t$ table, then $\mathrm{Ho}$ is rejected,

3. The significance level used is 5 percent, in other words if $P>0.05$ it is declared insignificant.

\section{RESULT AND DISCUSSION}

\section{Result}

Classical Assumption Test Results

1. Normality Test

The normality test used in this study is the Kolmogorov-Smirnov test, namely:

Table 2. One-Sample Kolmogorov-Smirnov Test

\begin{tabular}{llr} 
& & Unstandardized Residual \\
\hline N & & 100 \\
\hline Normal Parameters & Mean & .0000000 \\
\cline { 2 - 3 } & Std. Deviation & .29371118 \\
\hline Most Extreme Differences & Absolute & .079 \\
\cline { 2 - 3 } & Positive & .079 \\
\cline { 2 - 3 } & Negative & -.046 \\
\hline Test Statistic & & .079 \\
\hline Asymp. Sig. (2-tailed) & & $.131^{\mathrm{c}}$ \\
\hline
\end{tabular}

Wulan Wahyuni Rossa Putri, Nilda Tartilla and M. Nofal Pamungkas. Analysis Of The Factors That Affect The Company's Accounting Conservatism 
a. Test distribution is Normal.

b. Calculated from data.

c. Lilliefors Significance Correction.

Based on the Table 2, 0.131 is generated, it can be concluded that the research data does not occur residuals or is normally distributed because the value is $>0.05$.

2. Multicollinearity Test

Table 3. Multicollinearity

Coefficients $^{\text {a }}$



a. Dependent Variable: KA

When viewed from the VIF value table for the Leverage variable above 10 and tolerance below 0.1 , multicoll occurs, as is the case with the Financial Distress variable. Whereas for Capital Intensity, the VIF value is below 10 and the tolerance value is above 0.1 , there is no multicollinearity.

3. Heteroscedasticity Test

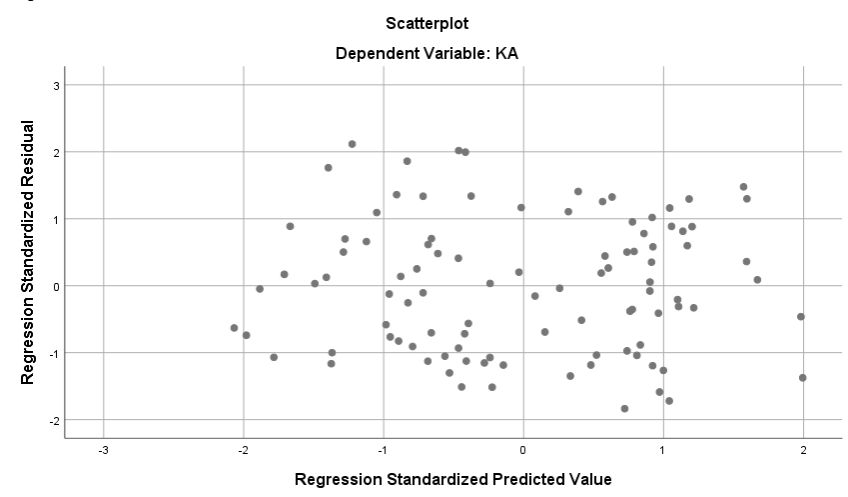

When viewed from the chart above, the distribution of dots occurs and a certain pattern is not formed, it can be concluded that heteroscedasticity does not occur.

4. Autocorrelation Test

Tabel 4. Autocorrelation Test Model Summary

\begin{tabular}{|c|c|c|c|c|c|c|c|c|c|}
\hline \multirow{2}{*}{\multicolumn{10}{|c|}{ Std. }} \\
\hline & & & & & & & & & \\
\hline $\mathrm{R}$ & $\begin{array}{c}\mathrm{R} \\
\text { Square }\end{array}$ & $\begin{array}{c}\text { Adjusted } \\
\text { R } \\
\text { Square }\end{array}$ & $\begin{array}{c}\text { Error of } \\
\text { the } \\
\text { Estimat } \\
\mathrm{e}\end{array}$ & $\begin{array}{c}\text { R Square } \\
\text { Change }\end{array}$ & $\begin{array}{c}\mathrm{F} \\
\text { Change }\end{array}$ & df1 & $\mathrm{df} 2$ & $\begin{array}{l}\text { Sig. F } \\
\text { Change }\end{array}$ & $\begin{array}{l}\text { Durbin- } \\
\text { Watson }\end{array}$ \\
\hline $.438^{a}$ & .192 & .167 & .29827 & .192 & 7.613 & 3 & 96 & .000 & 1.789 \\
\hline
\end{tabular}

a. Predictors: (Constant), IM, FD, LR

b. Dependent Variable: KA

Wulan Wahyuni Rossa Putri, Nilda Tartilla and M. Nofal Pamungkas. Analysis Of The Factors That Affect The Company's Accounting Conservatism 
When viewed from the table 4 , the DW value is 1.789 . The DU value for data is 100 and for variable 3 is 1.71517 and the value for $4-\mathrm{du}$ is $(4-1.71517=2.28483)$. So the DW value lies between du and 4-du. So it can be concluded that the regression model in this study does not occur autocorrelation.

\section{Multiple Linear Regression Analysis}

Table 5. Multiple Linear Regression Analysis

\section{Coefficients $^{\mathrm{a}}$}

\begin{tabular}{llr|r|r|r|r} 
Model & \multicolumn{2}{c|}{$\begin{array}{c}\text { Unstandardized Coefficients } \\
\text { Std. Error }\end{array}$} & $\begin{array}{r}\text { Standardized Coefficients } \\
\text { Beta }\end{array}$ & \multicolumn{1}{c|}{ t } & Sig. \\
\hline 1 & (Constant) & .325 & .109 & 2.985 & .004 \\
\cline { 2 - 8 } & LR & .522 & .879 & .229 & .594 & .554 \\
\hline & FD & -.068 & .362 & -.072 & -.187 & .852 \\
\hline IM & 1.176 & .322 & .357 & 3.656 & .000 \\
\hline
\end{tabular}

a. Dependent Variable: KA

Based on the table above, it can be presented in the regression equation as follows: $Y=$ $0.325+0.522$ LR -0.068 FD + 1.176 IM $+\varepsilon$

It can be concluded as follows:

1. A constant of 0.325 means that if the values of $X 1, X 2$ and $X 3=0$ or leverage and financial distress and capital intensity are 0 , then the value of the variable $y$ or accounting conservatism is 0.325 .

2. The leverage coefficient value is 0.522 which means that there is a straight comparison between the $X$ and $Y$ variables, that is, if the leverage increases, the accounting conservatism will also increase.

3. The value of the Financial Distress coefficient is -0.68 , which means that there is an inverse comparison between variables $X$ and $Y$, that is, if financial distress increases, accounting conservatism will decrease

4. The value of the Capital Intensity coefficient is 1.176 which means that there is a straight comparison between variables $\mathrm{X}$ and $\mathrm{Y}$, namely if capital intensity increases, accounting conservatism will decrease.

\section{t TEST}

Table 6. t-Test

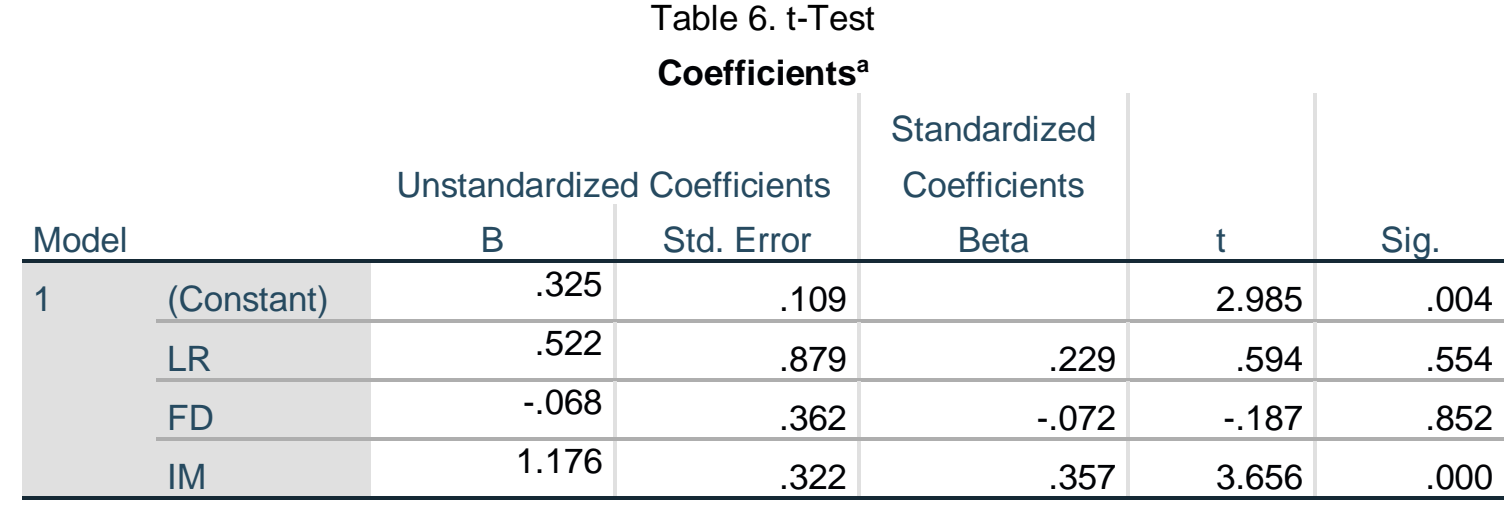

a. Dependent Variable: KA

Based on the table above, it can be concluded as follows:

1. Leverage

When viewed from the Sig Leverage value of 0.554 , while the standard set is 0.05 .

So that states that leverage does not affect accounting conservatism, so even if we look at the $t$ count value of 0.594 is smaller than the table of 1.985 . While the

Wulan Wahyuni Rossa Putri, Nilda Tartilla and M. Nofal Pamungkas. Analysis Of The Factors That Affect The Company's Accounting Conservatism 
standard set should be t count> $\mathrm{t}$ table.

2. Financial Distress

When viewed from the value of the Sig Financial Distress of 0.852 , greater than 0.05 .

And t count is 0.187 <from t table is 1.985 . So financial distress has no effect on accounting conservatism.

3. Capital Intensity

When viewed from the Sig value of Capital Intensity of 0,000 , it is smaller than the standard set at 0.05 . While t count of 3.656 is greater than $t$ table of 1.985 , so the capital intensity affects accounting conservatism.

\section{F TEST}

\section{Table 7}

\begin{tabular}{|c|c|c|c|c|c|c|c|c|c|}
\hline \multicolumn{10}{|c|}{ Model Summary ${ }^{b}$} \\
\hline & & & & & Cha & e Statis & & & \\
\hline $\mathrm{R}$ & $\begin{array}{c}R \\
\text { Square }\end{array}$ & $\begin{array}{l}\text { Adjusted R } \\
\text { Square }\end{array}$ & $\begin{array}{l}\text { Estim } \\
\text { ate }\end{array}$ & $\begin{array}{l}\text { R Square } \\
\text { Change }\end{array}$ & $\begin{array}{c}\mathrm{F} \\
\text { Change }\end{array}$ & df1 & df2 & $\begin{array}{l}\text { Sig. F } \\
\text { Change }\end{array}$ & $\begin{array}{l}\text { Durbin- } \\
\text { Watson }\end{array}$ \\
\hline $.438^{\mathrm{a}}$ & .192 & .167 & $\begin{array}{r}.2982 \\
7\end{array}$ & .192 & 7.613 & 3 & 96 & .000 & 1.789 \\
\hline
\end{tabular}

a. Predictors: (Constant), IM, FD, LR

b. Dependent Variable: KA

When viewed from the table above, it can be seen that $F$ count is 7,613 , while the $F$ table is 2.7. This means that $F$ count $>F$ table, so it can be concluded that the variable $X$ simultaneously or jointly affects the variable $\mathrm{Y}$, namely the variable leverage, financial distress and capital intensity have a simultaneous effect on accounting conservatism.

\section{DISCUSSION}

\section{Effect of leverage on Accounting Conservatism.}

Based on the results of hypothesis testing that has been done, it shows that leverage does not have a positive effect on accounting conservatism. Thus, Ha1 which states that leverage has a positive effect on accounting conservatism is rejected. The results of this study do not support the results of research conducted by Pratanda (2014) but do support the results of research conducted by Susanto and Ramadhani (2016) and Purnama and Daljono (2013) where leverage has no positive effect on accounting conservatism. The results of this research indicate that the size of the company's debt does not guarantee that the company will be more careful in preparing financial reports and in making decisions. It is assumed that creditors do not really supervise the operations and accounting operations of the company, thus providing flexibility for managers in conducting debt agreements. The company will choose an accounting method that increases company profits, which is inversely proportional to accounting conservatism in which the value of assets, profits and income is presented in an understate manner.

\section{Effect of Financial Distress on Accounting Conservatism.}

Based on the results of hypothesis testing that has been done, it shows that financial distress has no effect on accounting conservatism. The level of financial difficulty of the company cannot be used as an excuse for a manager to take opportunistic actions, namely by reporting high profits. In addition, the level of financial difficulty has no

Wulan Wahyuni Rossa Putri, Nilda Tartilla and M. Nofal Pamungkas. Analysis Of The Factors That Affect The Company's Accounting Conservatism 
relationship with conservative accounting practices. This research is in line with Ningsih (2013) who stated that financial distress has no effect on conservatism.

\section{Effect of Capital Intensity on Accounting Conservatism.}

Based on the results of hypothesis testing that has been done, it shows that the capital intensity in the hypothesis test results is accepted because there is a positive and significant influence between capital intensity and accounting conservatism. The results of this study support the research conducted by Sari and Adhariani (2009). In this study states that capital intensity has a positive and significant effect on accounting conservatism by using the calculation of non-operating accruals (NOA). It can be concluded that companies that are capital intensive are hypothesized to use accounting conservatism. As stated by Zmijewski and Hagerman (1981), which states that capital intensive companies are hypothesized to have greater political costs and are more likely to reduce earnings or financial statements tend to be conservative. This further shows that sales have more effect on political costs and the use of the principle of accountants' conservatism.

Leverage, Financial Distress, and Capital Intensity Have a Simultaneous or Joint Effect on Accounting Conservatism.

Companies listed on the IDX are large companies and certainly require large funds, both from investors who will invest and from creditors who will provide loans. Capital and loans that have been received by the company will be used properly for the smooth operation of the company. Companies in carrying out their business processes are certainly dealing with uncertainties that will occur in the future, including large companies and companies that are capital intensive. Companies that are large and capital intensive have a large business risk, just as companies that have large debts certainly bear large risks. To anticipate this, the manager of the company can determine the accounting policies needed for the company concerned, so it can be concluded that several factors such as the ratio of total debt to total assets owned, financial distress, and the intensity of the company's capital together have a significant effect on accounting policies, which will be applied in a company, in this study it is proven that these factors simultaneously have a significant effect on the application of the principle of accounting conservatism.

\section{CONCLUSIONS AND SUGGESTIONS}

\section{Conclusions}

Based on the discussion of the tests carried out, it can be concluded as follows:

1. Leverage does not affect accounting conservatism

2. Financial distress does not affect accounting conservatism

3. Capital intensity affects accounting conservatism

4. Simultaneous leverage, financial distress and capital intensity or together have an effect on accounting conservatism.

\section{Suggestion}

For further research, it is expected to examine other variables that can affect accounting conservatism, for example about company size, liquidity, and other factors. As well as the research subjects added above in 2017.

Wulan Wahyuni Rossa Putri, Nilda Tartilla and M. Nofal Pamungkas. Analysis Of The Factors That Affect The Company's Accounting Conservatism 


\section{REFERENCES}

Alfian, A. (2013). Analisis Faktor - faktor yang Berpengaruh Terhadap Pemilihan Konservatisme Akuntansi. Diponegoro Jurnal of Accounting, 2.

Beaver, W. H., \& Ryan, S. G. (2000). Biases and Lags in Book Value and Their Effects on the Ability of The Book-to-Market Ratio to Predict Book Return on Equity. Journal of Accounting Research, 38 (1), 127-148.

Ghozali, I. (2006). Analisis Multivariate dengan Program SPSS. Edisi Ke 4. Badan Penerbit Universitas Diponegoro. Semarang.

Hellman, N. (2007). Accounting Conservatism Under IFRS. Working Paper, Stockholm School of Economics.

Kim, Chansog (Francis), \& Zhang, L. (2013). Corporate Political Connections and Tax Aggressiveness. City University of Hong Kong.

Lailatul, A.. (2016). Faktor - faktor yang Mempengaruhi Konservatisme Akuntansi Sebelum dan Sesudah Adopsi IFRS. Artikel STIE Perbanas Surabaya.

Ningsih, E. (2013). Pengaruh Tingkat Kesulitan Keuangan dan Risiko Litigasi terhadap Konservatisme Akuntansi.

Noor, R.M, Syazwani, N., Fadzillah, M. \& Matsuki, N.A. (2010). Corporate Tax Planning: A Study on Corporate Effective Tax Rates of Malaysian Listed Companies. International Journal of Trade, Economics and Finance, 1 (2):189193.

Pratanda, R.S \& Kusmuriyanto. (2014). Pengaruh Mekanisme Good Corporate Governance, Profitabilitas dan Leverage terhadap Konservatisme Akuntansi. Accounting Analysis Journal,(3),.

Purnama, W. H \& Daljono. (2013). Pengaruh Ukuran Perusahaan, Rasio Leverage, Intensitas Modal, dan Likui ditas Perusahaan terhadap Konservatis me Perusahaan. Diponegoro Journal of Accounting, 2 (3) ISSN:2337-3806.

Rodini, A., \& Ali, H. (2010). Manajemen Keuangan. Jakarta: Mitra.

Sari, C., \& Adhariani, D. (2009). Konservatisme Perusahaan di Indonesia dan FaktorFaktor yang Mempengaruhinya. Makalah. Paper presented at Simposium Nasional Akuntansi XII. Padang.

Harahap,S.S. (2011). "Analisis Kritis atas Laporan Keuangan”. Jakarta: PT. Raja Grafindo Persada.

Susanto, B., \& Ramadhani, T. (2016), Faktor - Faktor yang Memepengaruhi Konservatisme, Jurnal Bisnis dan Ekonomi, 142-151.

Wulan Wahyuni Rossa Putri, Nilda Tartilla and M. Nofal Pamungkas. Analysis Of The Factors That Affect The Company's Accounting Conservatism 
The Accounting Journal of BINANIAGA Vol. 05, No. 02, December 2020

p-ISSN: 2527-4309, e-ISSN: 2580-1481

$5^{\text {th }}$ Accreditation Rating: January 14, 2019 - January 13, 2024

Utami, D.G. (2013). Pengaruh Debt To Total Assets, Dividen Payout Ratio Dan Ukuran Perusahaan Pada Konservatisme Akuntansi Perusahaan Manufaktur Di Bei. E - Journal Akuntansi Udayana.

Watts, R. L. (2003a). Conservatism in Accounting Part I: Explanations and Implications. Accounting Horizons, 17 (3), 207-221.

Zmijewski, M., \&. Hagerman ,R. (1981). "An Income Strategy Approach to the Positive Theory of Accounting Standard Setting/Choice". Journal of Accounting and Economics, 3, 129-149.

Wulan Wahyuni Rossa Putri, Nilda Tartilla and M. Nofal Pamungkas. Analysis Of The Factors That Affect The Company's Accounting Conservatism 